九州大学学術情報リポジトリ

Kyushu University Institutional Repository

\title{
A NEW GENUS AND SPECIES OF THE MIRIDAE FROM JAPAN (HEMIPTERA, HETEROPTERA)
}

Miyamoto, Syouichi

Yasunaga, Tomohide

https://doi.org/10.5109/2509

出版情報: ESAKIA. 26，pp.133-138，1988-01-25. Entomological Laboratory，Faculty of Agriculture, Kyushu University バージョン：

権利関係 : 


\title{
A NEW GENUS AND SPECIES OF THE MIRIDAE FROM JAPAN (HEMIPTERA, HETEROPTERA)*
}

\author{
Syôtтı Мічамото \\ Chikushi Jogakuen Junior College, \\ Dazaifu, Fukuoka, 818-01 Japan \\ and \\ TOMOHIDE YASUNAGA \\ Entomological Laboratory, Faculty of Agriculture, \\ Kyushu University, Fukuoka, 812 Japan
}

\begin{abstract}
Gigantomiris jupiter gen. et sp. nov. is described and illustrated from Japan. This is a considerably large species. The genus is primarily characterized by a combination of the small head and eyes, wide vertex, carinate pronotum, swollen mesonotum and short tibia1 spines.
\end{abstract}

This paper reports a finding of a very large, conspicuous species of the Miridae from Japan which represents a new genus and species. This species was once recorded as Hadrodemus sp. by Hasegawa (1960).

Before going further the authors wish to express their sincere thanks to the following entomologists for their kindness in offering them the valuable specimens: Prof. T. Saigusa (Biological Laboratory, College of General Education, Kyushu University), Assoc. Prof. M. Miyatake and Mr. S. Hisamatsu (Entomological Laboratory, Ehime University), Assoc. Prof. M. T. Châjô (Hikosan Biological Laboratory, Kyushu University), Dr. K. Baba (Niigata Pref.), Messrs. M. Iga (Tokyo Agricultural Experimental Station), T. Yano (Matsuyama City), I. Ôtsuka (Kumamoto City), S. Yoshimatsu and K. Konishi (National Institute of Agro-Environmental Sciences), R. Noda (Fukuoka City), S. Nomura and K. Yahiro (Entomological Laboratory, Kyushu University). The junior author is also much indebted to Prof. Y. Hirashima and Assoc. Prof. K. Morimoto of Entomological Laboratory, Kyushu University, for their kind guidance and encouragement. Their cordial thanks are also due to Assoc. Prof. M. T. Châjô and Mr. K. Takeno of Hikosan Biological Laboratory, Kyushu University for their kind permission to examine the valuable specimens.

* Contribution from the Entomological Laboratory, Faculty of Agriculture, Kyushu University, Fukuoka (Ser. 3, No. 255). 


\section{Gigantomiris gen. nov.}

Type species : Gigantomiris jupiter sp. nov.

Body large, elongate, subparallel-sided. Eyes relatively small, separated from pronotum ; head with eyes about half as wide as basal width of pronotum ; vertex wide ; antennal tubercule somewhat produced inwardly at its inner margin. First antennal segment compressed subbasally, without noticeable setae, 2nd segment gradually widened toward apex, about twice as long as 3rd, 3rd segment slightly longer than 4th. Rostrum short, not reaching middle coxa.

Pronotum carinate laterally, with indistinct short stiff hairs ; collar rather flat ; exposed part of mesonotum swollen ; scutellum convex, with semicircularly depressed portion. Hairs on hemelytra short, indistinct ; M-vein terminated at posterior $1 / 4$ of corium, not reaching anterior margin of cuneus ; cuneus long, slender, about 3 times as long as basal width. Legs long ; hind femur longer than abdomen in male ; tibial spines short ; 3rd segment of hind tarsus longer than 1st or 2nd.

Ventral surface of genital segment with median keel, Left paramere very thick ; hypophysis produced at right angle from subapical portion of sensory lobe. Right paramere with short claw-like hypophysis. Vesica bilobed, with a keel shaped elevation between lobes ventrally, without spicules ; each lobe subdivided into several lobules.

Remarks. Gigantomiris is a distinctive genus known by a very large species and having the relatively small head and eyes, wide vertex, produced inner margin of antennal tubercle, short rostrum, carinate pronotum, swollen mesonotum, long cuneus, short M-vein which is terminated at posterior $1 / 4$ of corium, and short tibial spines. The new genus belongs to the tribe Mirini, and is somewhat related to Miris Fabricius, which is European in distribution. Gigantomiris is easily distinguished from Miris by the pronotum carinate laterally for whole length and the hemelytra with distinct M-vein which is not reaching the cuneus.

\section{Gigantomiris jupiter sp. nov.}

Hadrodemus sp. Hasegawa, 1960, Bull. Nagaoka Municipal Sci. Mus., 1 : 50. (Japanese name : Akasuji-ô-mekuragame).

Size : In male body length $12.0 \mathrm{~mm}$, basal width of pronotum $2.9 \mathrm{~mm}$ and maximum width across hemelytra $3.3 \mathrm{~mm}$; those in female $13.0 \mathrm{~mm}$ long, $3.5 \mathrm{~mm}$ wide and $3.9 \mathrm{~mm}$ wide respectively.

Coloration : Very variable ; dorsal surface blackish brown, or with variegated reddish or yellowish brown striae.

Head black ; vertex with a pair of yellowish white markings; gena with irregular yellow markings behind eyes. Antenna black, 1st segment sometimes pale brown, 3rd segment pale basally. Rostrum shining dark brown.

Pronotum black, sometimes reddish or yellowish brown behind calli ; exposed part of mesonotum and scutellum entirely black; ostiolar peritreme yellowish brown. Hemelytra entirely blackish brown, or with reddish or yellowish brown striae on corium, clavus and cuneus ; membrane dirty dark grey, membrane vein pale brown distally. Legs blackish brown; femur pale brown basally ; tibia pale brown except at base and extreme apex.

Abdomen blackish brown ; posterior edge of each abdominal sternum paler.

Structure : Head almost smooth ; frons with minute punctures in several rows and with transversal wrinkles on 'anterior portion. Antenna with short pubescence, 1st segment hairless basally ; proportion of segments I to IV as $8: 23: 13: 12$ in $\sigma^{7}, 25: 81: 40: 37$ in $q$. Vertex a little less than 


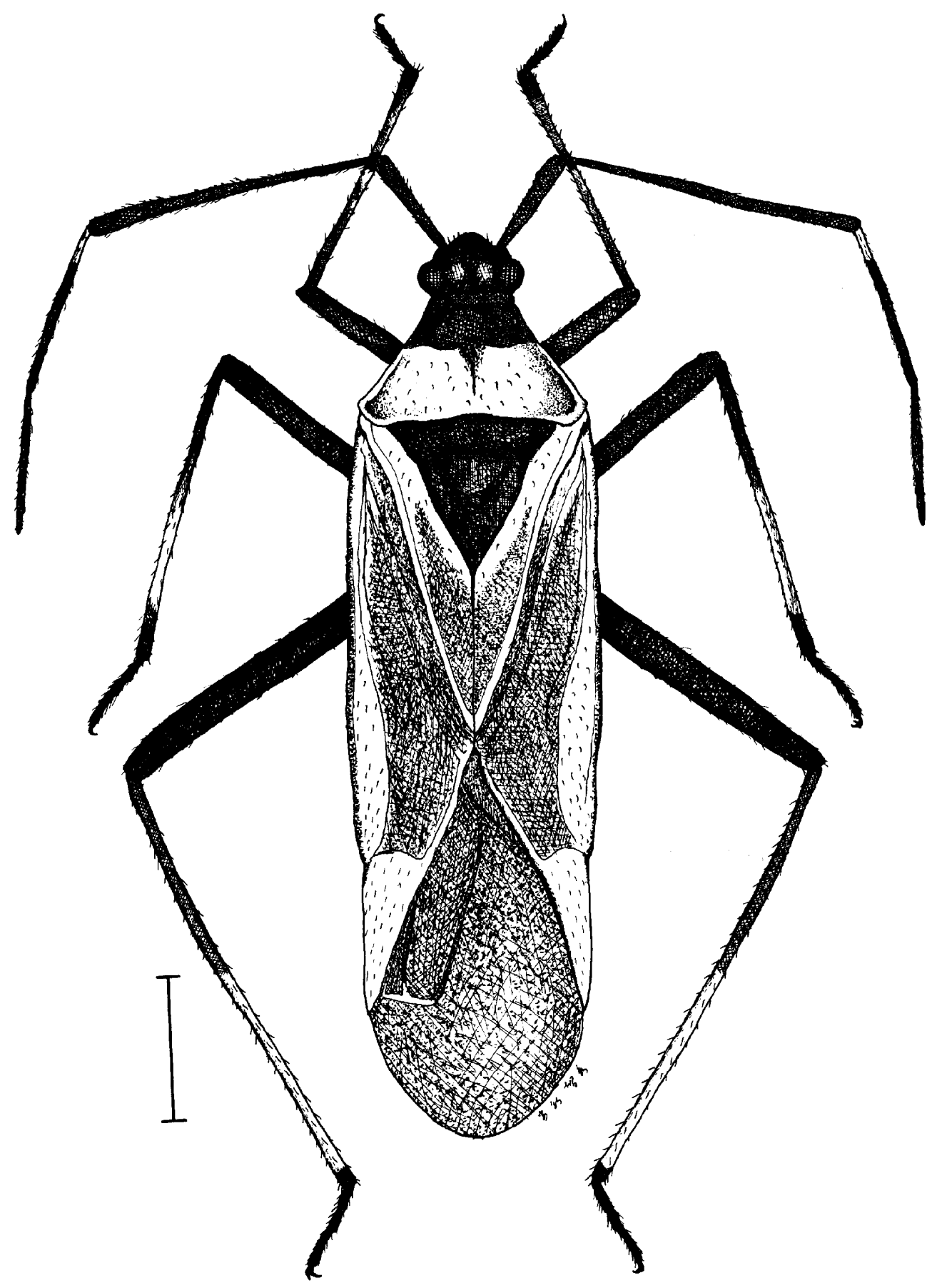

Fig. 1. Gigantomiris jupiter gen. et sp. nov., paratype male. Scale : $2 \mathrm{~mm}$. 


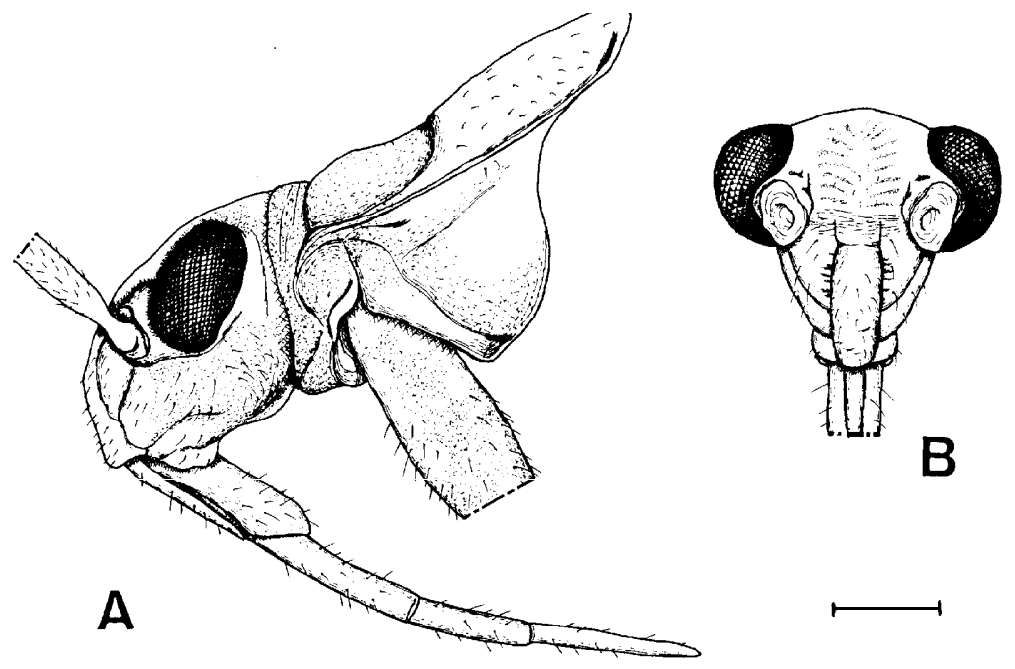

Fig. 2. Gigantomiris jupiter gen. et sp. nov., male. A, Head and pronotum in left lateral view ; $\mathrm{B}$, head in frontal view. Scale : $0.5 \mathrm{~mm}$.

half as broad as head (37:77 in $0^{\top}, 41: 89$ in $\left.\$\right)$; jugum bearing sparse hairs, with strong transversal wrinkles anteriorly; gula with some silky hairs ; clypeus relatively long. Proportion of rostal segments I to IV as 47: 44: 31: 45 in ơ, 54: 49: $35: 50$ in Q.

Pronotum irregularly punctate; collar rather flat, hairless, with some transversal wrinkles ; exposed part of mesonotum and scutellum nearly of a regular triangle, almost smooth. Hemelytra with indistinct short pubescence. First tarsal segment broader than the followings; proportion of femur : tibia : tarsus in hind pair as $14: 21: 4$ in $\sigma^{7}, 16: 24.5: 4.5$ in Q ; proportion of hind tarsal segments I to III as $10: 13: 15$ in o $11: 13: 16$ in + .

Male genitalia as described above.

HoLotype : ơ (Type No. 2645, Kyushu Univ.), Katsurakoba, Mt. Komagatake, Nagano Pref., Honshu, 26. vii. 1962, S. \& M. Miyamoto leg.

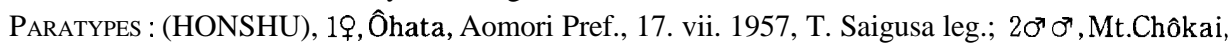
Yamagata Pref., 22. vi. 1977, K. Baba leg.; 19, Atsumi, Yamagata Pref., 15. vi. 1977, K. Baba leg.; 1 Ơ , Iidamachi, Yamagata Pref., 21. vi. 1977, K. Baba leg.; 10̛, Yunotaira, Mts. Iida, Yamagata Pref., 4. vi. 1966, K. Baba leg.; 1ㅇ, Ogunimachi, Yamagata Pref., 10. vi. 1977, K.Baba leg.; 107'same locality, 20-21. vi. 1977, K.Baba leg.; 19, Futakuchikeikoku, Akiumachi, Miyagi Pref., 12. vii. 1985, K. Konishi leg.; 19, Hinoemata, Fukushima Pref., 15. vi. 1986, S. Yoshimatsu leg.; 19, Hosono, Urabandai, Fukushima Pref., 9. vii. 1985, S. Nomura leg.; 19, Kurokawa, Niigata Pref., 11. v. 1972, K.Baba leg.; 26 ơ', same locality, 16. vi. 1976, K. Baba leg.; 19, Akadani, Niigata Pref., 13. vi. 1976, K. Baba leg.; $10^{7}$, Mt. Tanigawa, Gunma Pref., 17. vii. 1957, S. Hisamatsu leg.; 19, Mt. Nyûgasayama, Nagano Pref., 29. vii. 1962, S. \& M. Miyamoto leg.; $20^{\top}$ ơ, same locality, 31. vii. 1962, S. \& M. Miyamoto leg.; 29\%, 206, Kamikouchi, Nagano Pref., 21. vii. 1917, T. Esaki leg.; 19, 16, same locality, 24. vii. 1917, T. Esaki leg.; 2\%o, same locality, 5. viii. 1917, K. Takeuchi leg.; 19, same locality, 1. viii. 1959, M. Miyatake leg.; 19, Minoto, Mt. Akadake (2,000-2,500m), Mts. Yatsugatake, Nagano Pref., 27. vii. 1987, T. Yasunaga leg.; 19,10 , Mt. Amariyama, Yamanashi Pref., 8. vi. 1952, T. Saigusa leg.; 19,10 , Mt. 


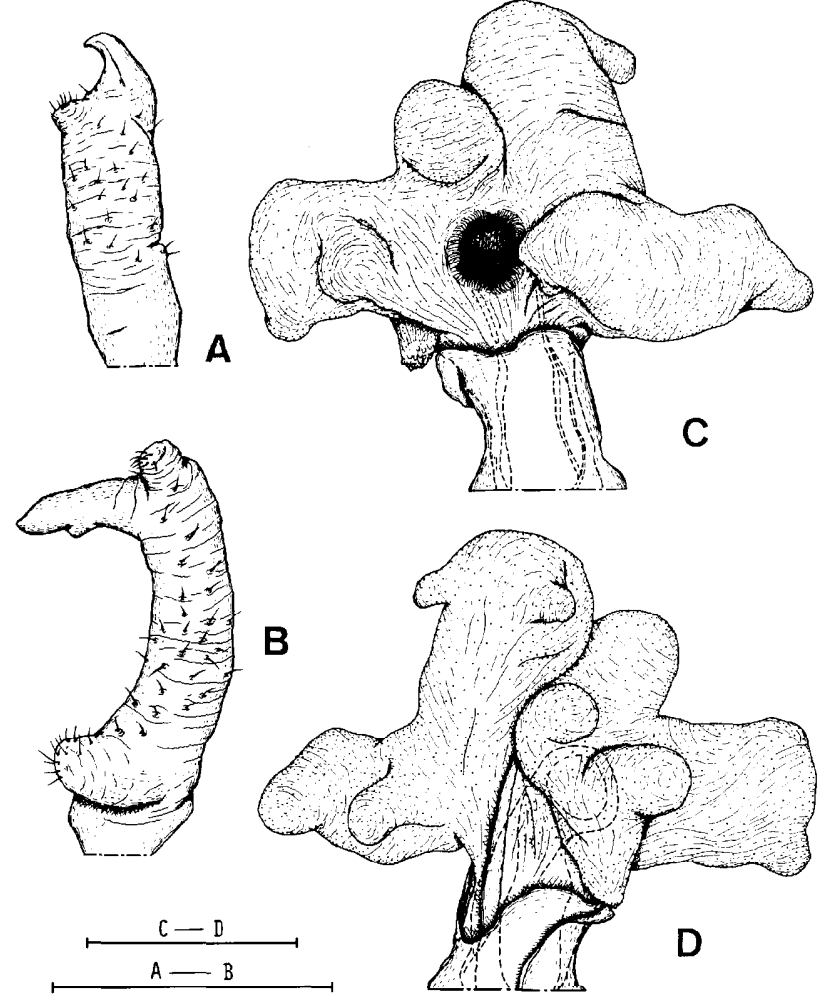

Fig. 3. Male genitalia of Gigantomiris jupiter gen. et sp. nov. A, Right paramere in dorsal view ; B, left paramere in dorsal view ; $\mathrm{C}$, vesica in dorsal view ; $\mathrm{D}$, ditto in ventral view. Scales : $0.5 \mathrm{~mm}$.

Ouginosen, Tottori Pref., 10. vi. 1963, T. Saigusa leg.; 3ơ ơ , Mt. Hôkidaisen, Tottori Pref., 9-10.v. 1981, M.T. Chajô leg.; 19,10̛', Mt. Kakezu, Geihokuchô, Hiroshima Pref., 10. vi. 1987, S. Miyamoto leg.; 19, same date and locality, K. Yahiro leg.; 10', same date and locality, T. Yasunaga leg.; 19, same locality, 27. vi. 1987, T. Yasunaga leg. (SHIKOKU), 19, Omogokei, Ehime Pref., 6. vi. 1952, T. Yano leg.; 19, Hoino, Dbgamori, Kôchi Pref., 11. vi. 1966, M. Iga leg. (KYUSHU), 1ơ, Mt. Hikosan, Fukuoka Pref., 11. vi. 1937, T. Esaki leg.; 19, Mt. Hômansan, Fukuoka Pref., 10. vi. 1963, T. Esaki leg.; 19, Mt. Kurodake, Mts. Kuja.,Ôita Pref., 9. vi. 1985, R. Noda leg.; 1ơ, same locality, 28. v. 1986, T. Yasunaga leg.; 299, 20 6, Mt. Hakuchô, Kumamoto Pref., 13. vii. 1977, I. Ôtsuka leg.; 20̛ ơ, same locality, 27-28. vi. 1987, R. Noda leg.; 19,10' , Izumimura, Kumamoto Pref., 11. vii. 1981, I. Ôtsuka leg.

Distribution. Japan (Honshu, Shikoku, Kyushu).

Remarks. This species is very variable in coloration, especially on the pronotum and hemelytra. In general the following three color variation are recognized : (1) pronotum and hemelytra entirely blackish, (2) when pronotum pale brown behind calli, hemelytra with pale brown striae, and (3) when pronotum reddish brown behind calli, hemelytra with reddish brown striae.

Gigantomiris jupiter has been collected by sweeping the herbaceous plants and the branches of broad-leaved trees in the montane regions. Mr. Y. Shôno collected both adults and nymphs of this species from the Japanese walnut, Juglans mandschurica (Onigurumi), and the junior author also 
collected a female adult from the Japanese walnut. Prof. T. Saigusa collected the male and female adults from Wisteria sp. (Fuji). Probably these are regarded as the host plants of Gigantomiris jupiter. This new species is the largest in the Japanese Miridae.

\section{References}

Carvalho, J. C. M., 1955. Chaves para os gêneros de Mirideos do mundo (Hemiptera). Bol. Mus. Goeldi, 11 (2) : 1-151, pls. 1-16.

Hasegawa, H., 1960. Heteroptera of Niigata Prefecture, Japan. Bull. Nagaoka Municipal Sci. Mus., 1: 19-63, pl. 1. (In Japanese.)

Kelton, L. A., 1959. Male genitalia as taxonomic characters in the Miridae (Hemiptera). Canad. Ent., $11: 3-72$.

Knight, H. H., 1923. Family Miridae (Capsidae). In W. L. Britton. Guide to the insect of Connecticut. Part IV. The Hemiptera or sucking insects of Connecticut. Bull.Conn.Geol. Nat. Hist. Surv., 34: 442-658.

Southwood, T. R. E. and D. Leston, 1959. Land and water bugs of the British Isles. Frederick Warne \& Co. Ltd., London \& New York.

Wagner, E. and H. H. Weber, 1964. Hétéroptères, Miridae. In Faune de France, 67 : 1-591. Librairie de la Faculté des Sciences, Paris. 